\title{
Vpliv vodenja na izobraževanje fizioterapevtov $v$ zdravstvenem domu
}

\author{
Arbulena Kokollari* \\ Univerza v Mariboru, Fakulteta za zdravstvene vede, Žitna ulica 15, 2000 Maribor, Slovenija \\ arbulena.kokollari@gmail.com
}

\begin{abstract}
Povzetek:
Raziskovalno vprašanje (RV): Zanima nas, ali se fizioterapevti $\mathrm{v}$ zdravstvenem domu izobražujejo, kdo jih največkrat spodbuja $\mathrm{k}$ temu, katera je njihova glavna ovira za izobraževanje in ali jim pridobljeno znanje iz izobraževanja pomaga pri njihovem delovnem procesu.

Namen: Namen raziskave je ugotoviti, ali način vodenja vpliva na odnos zaposlenih do izobraževanja in znanja.

Metoda: Izvedli smo eksperimentalno kvantitativno raziskavo, pri tem smo uporabili primarne in sekundarne vire podatkov. Primarne vire smo pridobili s pomočjo anketnega vprašalnika, za pridobitev sekundarnih virov pa smo uporabili deskriptivno raziskovalno metodo, in sicer na način sistematičnega pregleda slovenske in tuje literature.

Rezultati: Ugotovili smo, da se fizioterapevti večinoma sami spodbujajo k izobraževanju. Od vodij v zdravstvenem domu jih najbolj spodbuja glavni fizioterapevt. Kot osrednja ovira pri izobraževanju se je izkazalo finančno sredstvo. Fizioterapevti pa so zelo zadovoljni z izobraževanji, saj jim pridobljeno znanje iz izobraževanj zelo pomaga pri njihovem delovnem procesu.

Organizacija: Pridobljeni rezultati so v pomoč vodjem zdravstvenega zavoda in drugim zaposlenim z namenom opisa trenutnega stanja načina vodenja, izobraževanja in zadovoljstva zaposlenih. $Z$ interpretacijo teh vidimo, katera področja se še lahko izboljšajo za zagotavljanje bolj kakovostnih fizioterapevtskih storitev.

Družba: Izobraževanje ima pozitiven vpliv na zagotavljanju kakovostnih storitev, omogočanju boljšega izida postopka zdravljenja pacientov ter povečanju uspešnosti in učinkovitosti zavoda.

Originalnost: Zavod se lahko strokovno razvija le ob nenehnem poklicnem in osebnem razvoju zaposlenih, kar pa omogoča le stalno izobraževanje in izpopolnjevanje ter medsebojno sodelovanje zaposlenih. $\mathrm{Z}$ raziskavo smo pridobili prve podatke o izobraževanju fizioterapevtov na primarni ravni zdravstva v Sloveniji in vplivu načina vodenja nanj.

Omejitve/nadaljnje raziskovanje: Nadaljnje raziskave bi lahko raziskavo razširile na večjem raziskovalnem vzorcu. Tako bi lahko dobili tudi celostno sliko kakšno pozornost dajejo vodje izobraževanju zaposlenim fizioterapevtom na primarni ravni zdravstva v Sloveniji.
\end{abstract}

Ključne besede: zdravstveni dom, fizioterapija, vodenje, izobraževanje ob delu, spodbujanje k izobraževanju, ovire za izobraževanje.

\section{Uvod}

Napredek je danes del vsakega posameznega področja. Slediti napredku in s tem zagotoviti najvišjo kakovost dela, je potrebno dodatno izobraževanje in usposabljanje. To vodi v vseživljenjsko izobraževanje, ki se danes uvaja v sodobne organizacije ravno zaradi zahteve po permanentnem razvoju strokovne usposobljenosti. Organizacije po svetu in pri nas temu zato posvečajo posebno pozornost. Dober vodja se zaveda, da ima vodenje in veščine, ki so za to 
potrebne, velik vpliv na izobraževanje, razvoj in oblikovanje zavzetosti, pripadnosti in motivacije zaposlenih ter s tem na zagotavljanju dobrega poslovanja organizacije. $\mathrm{V}$ trendu vseživljenjskega izobraževanja, hitrega razvoja stroke fizioterapije in medicine ter ob vse bolj izobraževanem kadru mora vodja prevzeti vodenje, ki spodbuja samoaktualizacijo, samouresničevanje, samostojnost in odgovornost pri delu zaposlenih.

V zadnjem desetletju je fizioterapevtska stroka doživela bistveni razvoj. V tem obdobju smo priča sistematičnemu utemeljevanju učinkov in mehanizmov delovanja fizioterapevtskih postopkov z znanstvenimi dokazi. Torej pojavile so se nove znanstveno potrjene metode in tehnike fizioterapevtske obravnave, ki dajejo boljše rezultate, več različnih možnosti obravnav in bolj ciljno izvajanje terapije. Poglobljene raziskave funkcionalne anatomije in fiziologije nam odpirajo nove poglede na obstoječe tehnike, v določenih primerih ovržejo že poznane in jih nadomestijo z novimi. Zato je eden od temeljnih standardov razvoja in vzdrževanja kakovosti fizioterapevtskih storitev neprekinjen poklicni razvoj, saj je največja odgovornost fizioterapevta nudenje bolnikom kakovostno in sodobno obravnavo ter vzdrževanje in širjenje svojih profesionalnih kompetenc. Dejstvo je, da od zdravstvenih delavcev in od drugih zaposlenih v zdravstvu pričakujemo, da so vrhunski strokovnjaki za delo, ki ga opravljajo. Poslovna naravnanost vlaganj v znanja zaposlenih pa je še vedno stroškovna, ne pa razvojno naložbena. Takšno ravnanje ob togih in neustreznih položajih ustvarja dodatno nemotiviranost zaposlenih za spremembe.

Učenje je danes pomembnejše kot kdaj koli prej. Ljudje, ki se nenehno učijo in razvijajo svoje spretnosti ter so vse bolj dragoceni za organizacijo in na trgu dela. V okviru raziskovalne naloge nas zanima področje izobraževanja fizioterapevtov, ki so zaposleni v zdravstvenih domovih, in sicer področje neuradnega izobraževanja - spremljanje izsledkov raziskav, učenje novih metod in tehnik obravnav ter podobno. Zanima nas, ali se fizioterapevti v zdravstvenem domu dovolj izobražujejo oziroma sledijo napredku stroke. Ugotovili bomo, kakšno je njihovo delovno okolje, ali jih pri izobraževanju podpirajo ter ali se ustvarjajo takšni pogoji, da se pridobljeno znanje lahko neomejeno širi med vse zaposlene in se kreativno uporablja pri svojem delu. Prav tako nas zanima, kakšen vpliv ima vodja in način vodenja na odnos do izobraževanja in znanja. Danes znanje v organizaciji ni samemu sebi namen, ampak je pomembno sredstvo, s katerim uresničimo zastavljene cilje. Naprej bomo ugotavljali zainteresiranost fizioterapevtov kot posameznikov za izobraževanje ter ugotavljali subjektivne ovire za izobraževanje.

\section{Teoretična izhodišča}

\subsection{Vodenje v zdravstvenih organizacijah}

Opredelitev vodenja je skoraj toliko, kolikor je strokovnjakov, ki se z vodenjem ukvarjajo in o njem pišejo. Yukl (2010) je podal zelo splošno definicijo vodenja, in sicer da je proces, kjer ena oseba vpliva na drugo tako, da dosežejo določen cilj. Avtorji jo večinoma opredelijo podobno. Skupno vsem opredeljenim pa je, da gre za proces vplivanja na podrejene ali sodelavce, da delujejo tako, kot si je njihov vodja zamislil (Rozman et al., 2019, str. 302-303). Gre za 
kompleksno, strokovno zahtevno in odgovorno funkcijo, ki je vedno povezana z uspešnostjo organizacije. V okviru tega procesa poskušajo vodje s svojimi lastnostmi in vedenjem vplivati na zaposlene, jih usmerjati, motivirati ali kako drugače pripraviti do tega, da bi delo opravili najbolje (Rozman in Kovač, 2012, str. 350).

Vodenje je tudi sestavni del menedžmenta, ki predstavlja celoto znanja in usposobljenosti za usmerjanje posameznika ali skupine k postavljenim ciljem (Rozman in Kovač, 2012, str. 354). Iqbal, Anwar in Haider (2015, str. 1-6) so prepričani, da so uspešna podjetja rezultat uspešnega vodenja, pri čemer zaposleni potrebujejo nekoga, ki lahko usmerja ljudi k spremembam in izboljšanju njihove uspešnosti ter tako tudi uspešnosti celotne organizacije.

Proces vodenja zajema določanje ciljev podrejenih, delegiranje, komuniciranje, reševanje konfliktov, motiviranje in nadzorovanje. V procesu določanja ciljev podrejenih, vodja skupaj s podrejenimi razvija delovne cilje za podrejene in se o njih pogovarjajo. Pri tem naloga vodje ni samo postavitev ciljev zaposlenemu, temveč tudi spremljanje in pomoč pri izvajanju in doseganju ciljev (Pučko, 2002, str. 314-43). Naloga vodje je tudi delegiranje. Delegiranje pomeni prenašanje dela na druge in pooblaščanje sodelavcev za opravljanje nalog. Je proces, ki temelji na sodelovanju in omogoča rast vsakemu posamezniku, tako vodji kot tudi drugim članom tima. V tem procesu mora vodja poznati sposobnost zaposlenih in jim zaupati ustrezne naloge (Možina, 2002, str. 498-539). Pri tem ima pomembno vlogo komunikacija, ki predstavlja proces medsebojnega sporazumevanja. Opredeljena je tudi kot proces prenašanja informacij med vodilnimi in njihovimi podrejenimi z namenom medsebojnega vplivanja (Rozman et al., 2019, str. 320-321). Prav tako tudi sposobnost preprečevanja in reševanja konfliktov je kakovost uspešne vodje. Pogosto so konflikti v organizaciji merilo slabe organizacijske klime, vsak vodja pa želi imeti v timu dobro organizacijsko klimo, saj je ta pogoj za uspešnost organizacije. Pomembno je, da vodja ustvarja takšno organizacijsko kulturo, da se konflikti odpravljajo sprotno in ustrezno (Černetič, 2007). Uspešen vodja je motiviran, kajti jasno je, da vodja, ki ne more motivirati samega sebe, ne bo sposoben motivirati drugih. Zavedati se mora, da je motiviranost zaposlenih temelj uspešne organizacije in da je motiviranje zaposlenih stalen proces, saj ni dovolj, da jih samo motivira, ampak je treba njihovo motiviranost tudi ohraniti (Uhan Petek, 2008, str. 69-76). Na vse zadnje pa imamo še proces kontrole, ki se začenja z ugotovitvijo izvedbe, nadaljuje v primerjavi izvedbe $\mathrm{z}$ načrtom. Tako ugotavlja odstopanje, postavlja vzroke odstopanj in predlaga ukrepe za uspešno izvedbo zastavljenih ciljev. Lahko jo označujemo kot nenehno odločanje $\mathrm{z}$ namenom izvedbe načrta (Rozman in Kovač, 2012, str. 434).

Vodenja ni mogoče razložiti z enim samim načinom vodenja. Tudi v sodobni teoriji vodenja ostaja preučevanje stilov vodenja osrednji raziskovalni interes, ki se vse bolj pojavlja tudi v številnih razlagah procesa vodenja (Rozman in Kovač, 2012, str. 360). Najpomembnejši elementi, ki opredeljujejo stil vodenja, so jasna politika, način komuniciranja, priznanje zaposlenim, sposobnost zaposlenih vplivati na spremembe in poštenost (Abrams in Barrow, 
2005). V praksi zasledimo številne opredelitve in razčlenitve posameznih stilov vodenja. Nekateri so si med seboj podobni oziroma se prepletajo drug z drugim.

S stili vodenja se je ukvarjal že Weber, ki je opredelil štiri idealne stile vodenja: patriarhalni stil vodenja (od zaposlenih se pričakuje zvestoba in poslušnost), karizmatični stil vodenja (temelji na posebnih osebnostnih lastnostih vodje, torej na njegovi karizmi), avtokratični stil vodenja (značilna je hierarhična struktura) ter birokratski stil vodenja (treba je upoštevati elemente organizacije). Tudi Lewin je proučeval stile vodenja ter razlikoval dva, avtokratičnega in demokratičnega. Različni avtorji navajajo, ali povzamejo različne stile vodenja. Huber (2014) ter Marquis in Huston (2015) so opredelili tri stile vodenja, in sicer avtoritarnega, demokratskega in liberalnega. Značilnosti avtokratskega vodenja je centralizirano odločanje, ko vodja sprejme odločitev, upravlja svojo moč za ukazovanje in za nadzor drugih. Demokratsko vodenje je participativno, ko vodja upošteva tudi mnenja drugih, se z njimi posvetuje, seznani s problemom in posluša njihovo mnenje. Liberalno vodenje je pasivno in permisivno. Vodja pri sprejemanju odločitev prepušča veliko svobode podrejenim (Rozman et al., 2019, str. 307).

Izbira ustreznega stila vodenja mora slediti cilju, da zaposlene čim bolj spodbuja k učinkovitemu in ustvarjalnemu sodelovanju. Rozman in Kovač (2012, str. 362) navajata, da je bilo precej prepričanj o najboljšem načinu vodenja, ki bi bil učinkovit v vseh situacijah. Zagovornikov tega gledanja skoraj ni več. Zupančič (2015) meni, da idealnega stila vodenja ni. Danes velja, da vodje potrebujejo ustrezno znanje, sposobnost in spretnosti, da bi bili uspešni. Potrebujejo torej primerne kompetence ali zmožnosti. Nekatere kompetence so tehnične, na primer imeti analitične spretnosti, popolnoma razumeti zakonodajo, imeti sposobnost trženja in sposobnost pisanja. Druge kompetence pa se nanašajo na vedenje, denimo odločnost, podjetnost, sposobnost doseganja ravnotežja med delom in življenjem (Buchbinder in Shanks, 2012).

Kot smo že omenili, je vodenje kompleksen proces, v njem se pa nenehno spreminjajo okoliščine, delež in intenziteta številnih lastnosti konkretne osebe. Zato se številne študije, s katerimi odkrivajo ključne lastnosti uspešnosti vodij, pokazale nizko skladnost rezultatov (Kovač, Mayer in Jesenko, 2004). Česen (2003) trdi, da mora vodja, ki vodi organizacijo ali javni zavod imeti še dve pomembni lastnosti: biti mora vrhunski strokovnjak in tudi karizmatičen. S karizmo motivira člane tima, da mu sledijo, kot strokovnjak pa ima podporo zaposlenih s strani znanja. Vodenje je učinkovito le, če temelji na zaupanju in spoštovanju ter je zasnovano na kulturi, etiki in morali. Dober vodja je tisti, katerega misli so usklajene z besedami in dejanji. Zupančič (2015) pravi, da ni enega samega učinkovitega stila vodenja, vsi imajo prednosti in slabosti. Najuspešnejše vodje so tiste, ki so sposobne prilagoditi stil vodenja razmeram in zaposlenim, zato pa potrebujejo ustrezna znanja s področja vodenja.

\subsection{Menedžment $\mathbf{v}$ zdravstvenih organizacijah}

Menedžment se v zdravstvenih organizacijah izvaja na treh ravneh: vrhnji ali strateški, srednji in nižji ali operativni ravni. Na vrhnji ravni imamo direktorje zavoda, ki delujejo kot 
menedžerji. Od funkcij vodje tukaj prevladuje načrtovanje, manjši pa je delež vodenja. Na srednji ravni organizacijske strukture kliničnih središč, zdravstvenih domov in bolnišnic so organizacijske klinike, službe in oddelki ter enote $\mathrm{z}$ dispanzerji in ambulantami, ki jih vodijo predstojniki, in zdravstveno nego glavna medicinska sestra. Vodja je na tej ravni odgovoren za poslovanje organizacijske enote, za racionalno porabo sredstev ter za njeno učinkovito delovanje. Prav tako je odgovoren tudi za strokovno, izobraževalno in raziskovalno delo, smotrno organizacijsko delo, ustrezno strokovno usposobljenost osebja in strokovni razvoj v skladu z ekonomskimi možnostmi. S svojim vodenjem zaposlenih pripomore k poslovalnemu uspehu celotnega zdravstvenega zavoda ter k doseganju postavljenih ciljev v skladu z vizijo in strategijami zavoda. Na nižji ravni se funkcija vodenja sodelavcev izvaja v zdravstvenih, negovalnih, multidisciplinarnih in drugih timih. Zaradi zahtevnosti in raznolikosti dela ter različnosti pacientov delo ne more potekati $\mathrm{v}$ hierarhičnih skupinah, temveč $\mathrm{v}$ timih. Hiter razvoj medicinske znanosti in razvoj tehnologij onemogočata, da bi posameznik obvladoval vsa področja in vse procese v zdravstvu, zato je nujno medpoklicno sodelovanje in delo v timih. Člani timov so odgovorni za neposredno izvajanje nalog, vodja pa jim delegira naloge, usklajuje njihovo delo, vodi sestanke tima in sprotno rešuje probleme, ki se pojavljajo pri izvajanju neposrednega dela (Rozman et al., 2019, str. 78-79).

Ker imamo v zdravstvu opravka z ljudmi, je to delo zelo zahtevno, saj imajo ti različne vrednote in prepričanja ter različne zdravstvene probleme. Njihovo reševanje zahteva od zdravstvenih strokovnjakov veliko znanja, različnih spretnosti, empatije in humanega odnosa. Za uspešno reševanje zdravstvenih problemov je treba povezati na dokazih utemeljeno medicino in druge zdravstvene stroke ter različne strokovnjake, kar zahteva medpoklicno sodelovanje, od vodje pa znanje in izvajanje timskega vodenja (Pahor, 2014).

Pojem učeča se organizacija je dokaj nov, ta dojema organizacijo kot dinamičen sistem, ki ima zmožnost samospreminjanja in sposobnost razvijanja, s čimer optimalno zadovoljuje spreminjajoče se zahteve organizacijskih nosilcev interesov. Koncept je izhodišče za vsako učenje in razvoj, tako posameznikov kakor tudi organizacij (Vukovič, 2006, str. 47).

Učeča se organizacija je usmerjena na kontinuirano izboljševanje procesov, proizvodov in storitev. Ta sistematično pospešuje učenje zaposlenih in se nenehno spreminja zato, da bi dosegla svoje strateške cilje ter ohranila svojo konkurenčnost. Moč učeče se organizacije je v njeni sposobnosti, da identificira, uporablja, razvija in stimulira znanje, ki je na voljo. Razvoj človeških potencialov lahko delovne organizacije stimulirajo z različnimi dejavnostmi $\mathrm{v}$ delovni organizaciji in zunaj nje. Neuradno pridobivanje znanja, spretnosti, sposobnosti na delu, je odvisna od individualnosti, sposobnosti za samoučenje, strukture dela, razvitosti pogojev za učenje ter celotne socialno-kulturne klime (Urh, 2003, str. 122-139).

\subsection{Kariera in izobraževanje odraslih ob delu}

Vse uspešne organizacije vlagajo veliko finančnih naložb v izobraževanje svojih zaposlenih. Vsaka organizacija ima razvojni cilj in strategijo, ki jih poskuša uresničiti z lastnimi viri. Eden ključnih virov so zagotovo zaposleni, ki imajo največji potencial za doseg želenih rezultatov 
(Pavlin, 2015). Zato mora menedžment v organizaciji nameniti veliko pozornost izobraževanju kadrov in razvoju kariere posameznika.

V današnji družbi so osrednji razlogi za izvajanje izobraževanja, predvsem v vlogi izobraževanja v novi tehnološki družbi, izobraževanje kot dejavnik enakosti ali neenakosti v družbi in stalno ter hitro spreminjajoča se družba (Barle in Bazenšek, 2006). Na splošno lahko izobraževanje razdelimo glede na to, $\mathrm{v}$ kateri fazi izobraževalne kontinuitete je prisotno. Začetno izobraževanje traja vse od vstopa $\mathrm{v}$ šolo in izstopa iz nje. Tako pridobi posameznik temeljno ali poklicno izobrazbo, s katero se pripravi na življenje in delo. Nato nastopi nadaljevalno izobraževanje, ko posameznik ponovno vstopi v izobraževalni proces ter pridobi višjo izobrazbo, se usposablja in izpopolnjuje. Ta je vezana na izobraževanje odraslih, kjer se razvija osebnostna rast in pridobiva znanje za življenje in delo (Možina, 2003).

Izobraževanje odraslih se od izobraževanja otrok in mladih razlikuje v tem, da imajo odrasli že določene življenjske in delovne izkušnje, predhodno znanje, predvsem pa se za izobraževanje odločajo prostovoljno in vedo, zakaj se učijo. Tudi motivi za učenje so v odrasli dobi drugačni kot v času rednega izobraževanja. Izobraževanje odraslih razvrstimo v štiri temeljne kategorije: uradno izobraževanje za pridobitev javno priznane stopnje splošne izobrazbe, uradno izobraževanje za pridobitev javno priznane stopnje strokovne ali poklicne izobrazbe, neuradno splošno izobraževanje in neuradno izobraževanje za poklic in delo (usposabljanje, izpopolnjevanje). Kot smo že omenili, se odrasli večinoma sami odločajo za izobraževanje in so za to tudi motivirani, vendar lahko na poti pri odločitvi naletijo na različne ovire. Velikokrat te posameznika odvrnejo od izobraževanja, ker ni dovolj močan, da bi oviro premagal ali jo odstranil (Vukovič, 2006, str. 18-33). Glavne skupine ovir pri izobraževanju odraslih so situacijske ovire, ki izhajajo iz človeškega trenutnega položaja (stroški izobraževanja, družinski problemi in oddaljenost izobraževalne organizacije), institucijske ovire, kjer gre za ponudbo ustreznih študijskih programov ali tečajev ter dispozicijske ovire, ki so povezane s psihološkimi značilnostmi posameznikov (podoba o samem sebi, samozavest, stališča, zmožnost za učenje, odnos do izobraževanja, stopnja aspiracije) (Jelenc, 1996, str. 46-47).

Temeljni standardi za fizioterapevtsko prakso navajajo, da je neprekinjen strokovni razvoj proces, s katerim fizioterapevt ohranja in razvija svoje spretnosti, znanje in kompetence za učinkovito klinično prakso. Je sistematičen in cikličen proces, opravljen v času posameznikove kariere za razvoj in povečanje delovne spretnosti ter pri skrbi za pacienta. V Kodeksu etike fizioterapevtov je zapisana zaveza za izvajanje kakovostne obravnave, ki med drugimi temelji tudi na udeleževanju neprekinjenega strokovnega razvoja oziroma kakovostnem formalnem izobraževanju in strokovnem izpopolnjevanju. ZFS (Združenje fizioterapevtov Slovenije) je član Svetovne zveze za fizioterapijo (WCPT) in si prizadeva ob upoštevanju mednarodnih priporočil (Minimalni standardi stalnega poklicnega razvoja fizioterapevtov) nuditi članom kakovosten podiplomski poklicni razvoj (Združenje fizioterapevtov Slovenije, 2019).

Po opredelitvi teoretičnih izhodišč in sistematičnem pregledu dosedanjih raziskav s področja izobraževanja fizioterapevtov smo zasledili, da je zelo malo raziskav ter, da bi bilo koristno 
raziskovati na tem področju za bolj kakovostno delo fizioterapevtov. V ta namen smo želeli ugotoviti, ali način vodenja vpliva na odnos zaposlenih fizioterapevtov do izobraževanja in znanja.

Na podlagi strokovne literature, raziskovalnega problema in zasnovanega vprašalnika smo zastavili naslednja raziskovalna vprašanja:

RV 1: Zanima nas, ali se zaposleni fizioterapevti v zdravstvenem domu izobražujejo.

RV 2: Zanima nas, kdo spodbuja največkrat fizioterapevte, zaposlene v zdravstvenem domu, k izobraževanju.

RV 3: Zanima nas, katera je glavna ovira za izobraževanje fizioterapevtov, zaposlenih v zdravstvenem domu.

RV 4: Zanima nas, ali pridobljeno znanje iz izobraževanja pomaga fizioterapevtom, zaposlenih v zdravstvenem domu, pri delovnem procesu.

\section{Metoda}

Izvedli smo eksperimentalno, kvantitativno raziskavo. Pri tem smo uporabili primarne in sekundarne vire podatkov. Primarne vire smo pridobili s pomočjo anketnega vprašalnika, ki smo ga porazdelili med zaposlene fizioterapevte $\mathrm{v}$ zdravstvenem domu. Za pridobitev sekundarnih virov pa smo uporabili deskriptivno raziskovalno metodo, in sicer na način sistematičnega pregleda slovenske in tuje literature: znanstvene in strokovne članke, knjige in priročnike iz naslednjih baz podatkov: COBISS in Google Scholar. Za iskanje publikacije v slovenskem jeziku smo uporabili naslednje ključne besede v slovenskem jeziku: zdravstveni dom, fizioterapija, vodenje, izobraževanje ob delu, spodbujanje k izobraževanju, ovire za izobraževanje. Za iskanje publikacije $\mathrm{v}$ angleškem jeziku pa smo uporabili naslednje ključne besede $\mathrm{v}$ angleškem jeziku: health center, physiotherapy, guidance, education at work, encouragement to education, barriers to education.

Anketni vprašalnik smo pripravili s pomočjo literature. Sestavljen je bil iz 13-ih vprašanj. Prvi del ankete se je nanašal na demografske podatke: spol, starost, dosežena stopnja izobrazbe in dolžina delovne dobe. Drugi del ankete pa je vseboval devet vprašanj zaprtega tipa, kjer so bili možni odgovori podani, anketiranec se je moral le odločiti za ustrezen odgovor in ga obkrožiti. Vprašanja so se nanašala na izobraževanje fizioterapevtov, širjenje znanja izobraževanja, spodbujanje $\mathrm{k}$ izobraževanju, ovire pri izobraževanju in koristi znanja izobraževanja $\mathrm{v}$ delovnem procesu. Odločitev za sodelovanje anketirancev je potekalo prostovoljno. Vprašalnik je bil anonimen. V raziskovalni vzorec smo zajeli sedem fizioterapevtov, mladih in odraslih, različnih starostih skupin, iz zdravstvenega doma. Od tega je bilo šest oseb ženskega spola, kar znaša 85,71 \% vseh anketiranih ter ena oseba moškega spola, kar znaša 14,29 \% vseh anketiranih. Pridobljene podatke smo s pomočjo računalniških programov Microsoft Excel in Microsoft Word obdelali ter jih grafično in pisno prikazali. 


\section{Rezultati in razprava}

Znanje je ena ključnih prednosti sodobnih organizacij. Pri tem predstavlja pomembno vlogo vodja, ki z ustrezno politiko vodenja usmerja zaposlene $\mathrm{k}$ vedno večji težnji po novem znanju. Posledično se razvijajo zaposleni z visoko stopnjo intelektualnega kapitala, ki predstavlja konkurenčno prednost organizacije. $\mathrm{V}$ ta namen smo preučili trenutno situacijo pri zaposlenih na področju fizioterapije v enem izmed zdravstvenih domov Slovenije.

V okviru raziskovalne naloge smo želeli ugotoviti, ali se fizioterapevti v zdravstvenem domu dovolj izobražujejo, katera je glavna ovira za izobraževanje, kdo jih največkrat spodbuja k izobraževanju in ali jim pridobljeno znanje iz izobraževanja pomaga pri njihovem delovnem procesu. $\mathrm{V}$ ta namen smo v mesecu decembru 2019 izvedli raziskavo s pomočjo anketnega vprašalnika. $\mathrm{V}$ raziskavi je sodelovalo sedem fizioterapevtov, zaposlenih $\mathrm{v}$ zdravstvenem domu. Od teh jih je bilo šest ženskega spola in en moškega spola, in sicer iz različnih starostnih skupin.

Na podlagi izsledkov študijske strokovne literature in člankov smo si zastavili štiri raziskovalna vprašanja, ki jih bomo v nadaljevanju podrobneje predstavili.

Pri prvem raziskovalnem vprašanju nas je zanimalo, ali se fizioterapevti v zdravstvenem domu izobražujejo. Skozi raziskavo (glej tabelo 1) smo ugotovili, da sta se dva anketiranca v zadnjih dveh letih udeležila na več kot tri izobraževanja $(28,57 \%)$, medtem ko so se ostali anketiranci udeležili le treh ali manj izobraževanj $(71,43 \%)$. Tako lahko trdimo, da se fizioterapevti v zdravstvenem domu udeležujejo izobraževanj, vendar je še vedno čutiti potrebo po še več, saj so anketiranci mnenja, da se ne izobražujejo dovolj $(71,43 \%)$. V pregledu literature smo zasledili, da so tega mnenja bili tudi anketirani fizioterapevti v slovenskih bolnišnicah (Jereb Medved, 2006). Vzrokov za to je več, eden izmed njih so ovire, ki zavrnejo fizioterapevte od izobraževanja. Drugi vzrok pa je premalo motiviranje fizioterapevtov k izobraževanju s strani zavoda, kajti ti z dodatnim izobraževanjem na delovnem mestu ne pridobijo višjo plačo, finančno podporo ali drugo delovno mesto, vendar le možnost napredovanja pri delu. Koristno je, da zavod zaposlene motivira in spodbuja $\mathrm{k}$ izobraževanju, saj je vlaganje $\mathrm{v}$ znanje danes najboljša naložba. Fizioterapevti z novim znanjem iz izobraževanj, ki temelji na podlagi novih znanstveno potrjenih metodah in tehnikah, dosegajo boljše rezultate pri delu. Tako omogočamo tudi boljši izid postopka zdravljenja pacientov in uspešnost ter učinkovitost zavoda.

Tabela 1. Udeležba zaposlenih fizioterapevtov v zdravstvenem domu na izobraževanjih

\begin{tabular}{lll}
\hline Odgovor & Število $(\mathbf{N})$ & Povprečje (\%) \\
\hline Več kot 3 & 2 & 28,57 \\
3 ali manj & 5 & 71,43 \\
Skupaj & 7 & 100 \\
\hline
\end{tabular}


Pri drugem raziskovalnem vprašanju nas je zanimalo, kdo največkrat spodbuja fizioterapevte k izobraževanju. Iz rezultatov (glej sliko 1) smo razbrali, da se fizioterapevti pogosto sami spodbujajo k izobraževanju ali jih spodbuja narava dela. Občasno jih spodbuja glavni fizioterapevt, redko predstojnik oddelka ali domači in nikoli jih ne spodbujajo drugi zaposleni. Glede na povprečje lahko trdimo, da se fizioterapevti v zdravstvenem domu največkrat spodbujajo sami k izobraževanju. Kot smo že omenili v teoretičnem delu, so odrasli sami motivirani za izobraževanja, kar je tudi razvidno iz naših rezultatov. Podobno mnenje so imeli tudi anketirani fizioterapevti v slovenskih bolnišnicah (Jereb Medved, 2006). Motiviranje in spodbujanje $\mathrm{k}$ izobraževanju zaposlenih $\mathrm{s}$ strani glavnega fizioterapevta je $\mathrm{v}$ večji meri $\mathrm{v}$ primerjavi z ostalimi nadrejenimi. Ti se morajo zavedati, da je za uspešno in konkurenčno organizacijo treba spremljati pojave novejših znanstveno potrjenih fizioterapevtskih metod in tehnik ter zaposlene usposabljati. Le na ta način lahko izboljšamo kakovost storitev, ki pa je temelj konkurenčne prednosti dobrih organizacij.

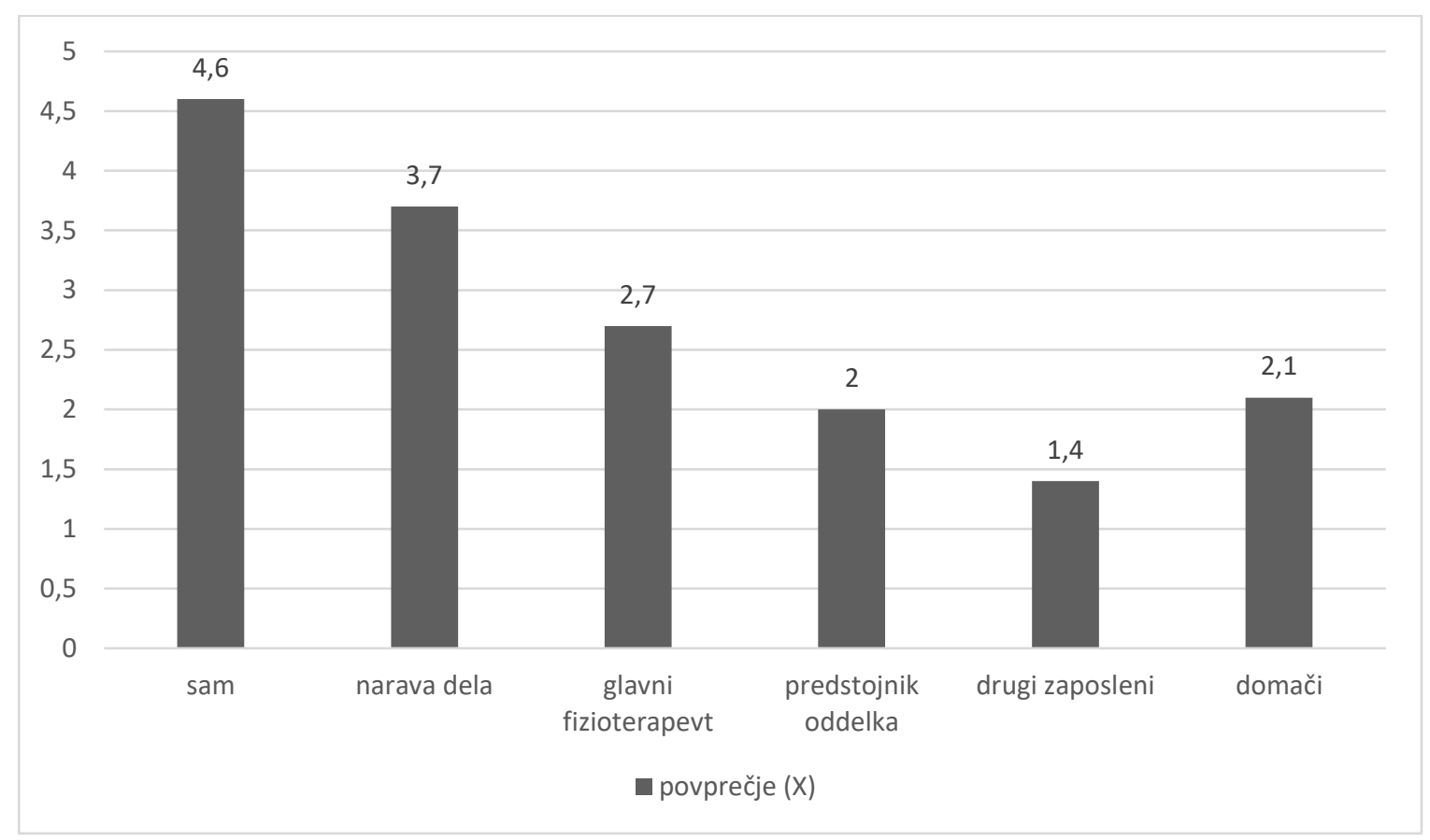

Slika 1. Stolpčni grafikon o spodbujanju zaposlenih fizioterapevtov k izobraževanju

Pri tretjem raziskovalnem vprašanju nas je zanimalo, katera je glavna ovira za izobraževanje fizioterapevtov $\mathrm{v}$ zdravstvenem domu. Iz rezultatov raziskave (glej sliko 2) smo razbrali, da je pogosto osrednja ovira za izobraževanje finančno sredstvo. Občasno jih ovira nestrokovnost izvajalcev izobraževanja in redko neprimeren čas za izobraževanje, nezanimiva vsebina ter premalo sodobnih izobraževanj. Glede na povprečje lahko trdimo, da je glavna ovira za izobraževanje fizioterapevtov $\mathrm{v}$ zdravstvenem domu predvsem finančno sredstvo. Ta je predstavljala glavno oviro tudi pri raziskavi med anketiranimi fizioterapevti $\mathrm{v}$ slovenskih bolnišnicah (Jereb Medved, 2006). Potrebna finančna sredstva, ki jih nameni zdravstveni dom za izobraževanje fizioterapevtov, je premalo, zato je treba poiskati druge finančne vire. Ena možnost je poiskati pokrovitelje, saj uspešna podjetja velikokrat namenijo finančna sredstva za 
donacijo. Kot smo že omenili, je vlaganje v znanje danes ena najpomembnejših naložb in smo zato prepričani, da bi bila ta možnost uspešna rešitev težave. V drugem primeru pa bi lahko fizioterapevti pripravili strokovne brošure s strokovnimi navodili in nasveti, ki bi jih dobili pacienti. V brošurah pa bi priložili položnico za prostovoljni prispevek, ki bi ga pacienti nakazali na transakcijski račun fizioterapevtov v zdravstvenem domu.

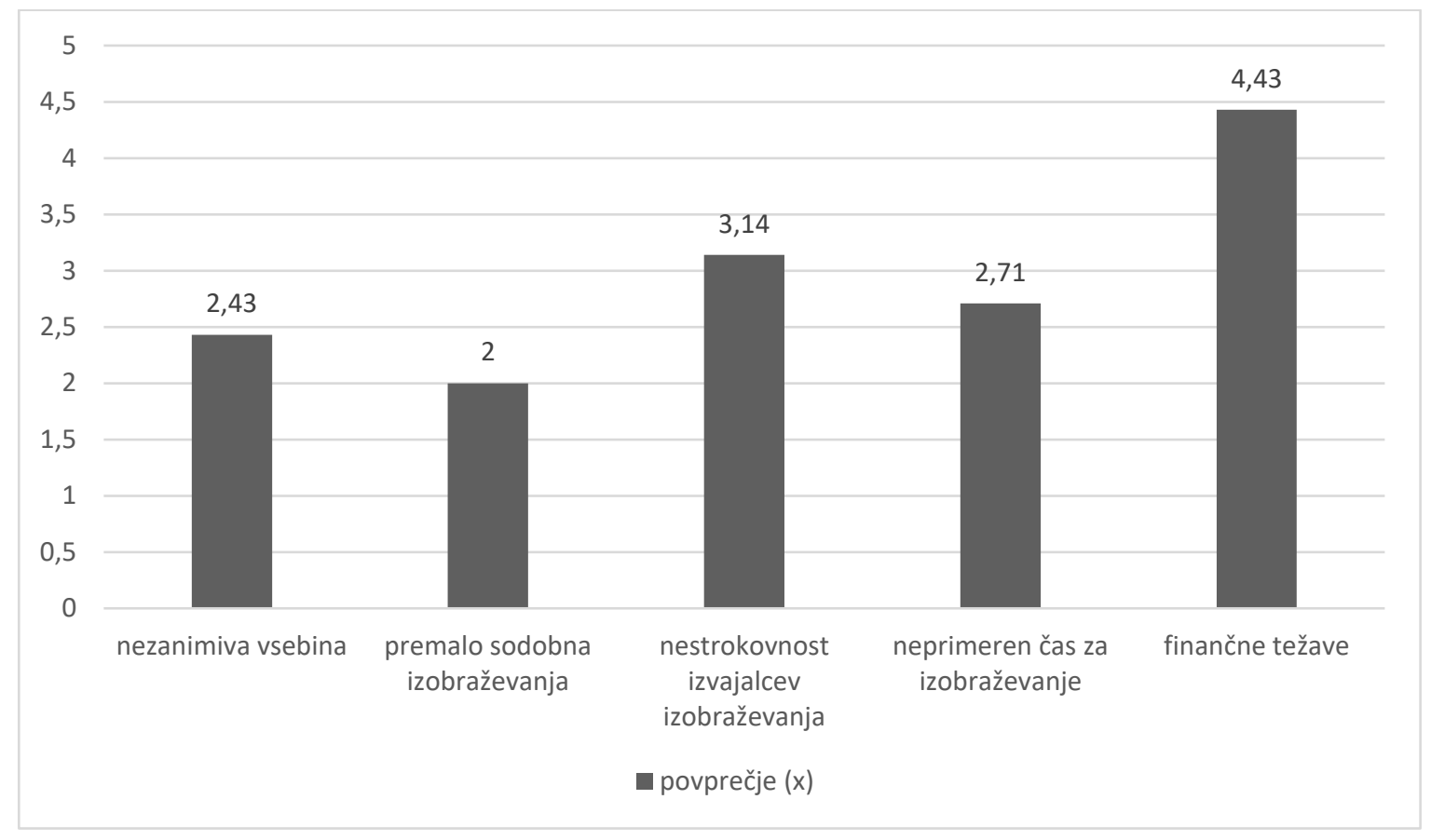

Slika 2. Stolpični grafikon o subjektivnih ovirah za izobraževanja zaposlenih fizioterapevtov

Pri četrtem raziskovalnem vprašanju nas je zanimalo, ali pridobljeno znanje iz izobraževanja pomaga fizioterapevtom $v$ delovnem procesu. Iz rezultatov (glej tabelo 2) smo razbrali, da $71,43 \%$ anketiranih fizioterapevtov meni, da jim znanje izobraževanja vedno pomaga pri delovnem procesu. Vsi drugi pa menijo, da jim znanje izobraževanja pomaga le občasno. Z višjim povprečjem je izstopalo, da znanje izobraževanja pomaga fizioterapevtom v delovnem procesu, kar kaže, da se fizioterapevti z veseljem udeležujejo izobraževanja ter da izvajajo kakovostne storitve, ki zagotavljajo boljše rezultate in večji uspeh pri delu.

Tabela 2. Vpliv izobraževanja na delovni proces fizioterapevtov

\begin{tabular}{lll}
\hline Odgovor & Število $(\mathbf{N})$ & Povprečje (\%) \\
\hline Vedno & 5 & 71,43 \\
V̌̌asih & 2 & 28,57 \\
Nikoli & 0 & 0,00 \\
Skupaj & 7 & 100 \\
\hline
\end{tabular}




\section{Zaključek}

Organizacija se lahko strokovno razvija le ob nenehnem poklicnem in osebnem razvoju zaposlenih, kar pa omogoča le stalno izobraževanje in izpopolnjevanje ter medsebojno sodelovanje zaposlenih. Pri tem pa je ena izmed temeljnih nalog vodij usmerjanje in spodbujanje zaposlenih k inovativnosti, kreativnosti, iskanju vedno novih znanj ter posledično prenašanju znanja v timu. Navsezadnje je zdravstveni dom tudi učeča se organizacija, kar pomeni, da skrbi za prenašanje znanja in izobraževanje mlajšim generacijam, ki bodo čez nekaj let v njej tudi zaposleni.

$\mathrm{Z}$ raziskavo smo ugotovili, da se fizioterapevti $\mathrm{v}$ zdravstvenem domu izobražujejo, pri tem se večinoma spodbujajo sami ali jih spodbuja narava dela. Od vodij v zdravstvenem domu pa jih $\mathrm{k}$ temu največkrat spodbuja glavni fizioterapevt. Naloga vodje je, da skupaj z drugimi zaposlenimi določijo potrebna znanja, ki jih lahko potrebujejo $\mathrm{z}$ dodatnim strokovnim izobraževanjem ter se nato tudi izobražujejo. Dokazali smo, da je glavna ovira pri izobraževanju fizioterapevtov $\mathrm{v}$ zdravstvenem domu finančno sredstvo. Večina anketirancev ni bila pripravljenih oziroma niso sposobni sami v celoti plačevati izobraževanja, kar se zelo dobro vidi v odgovoru večine, da izobraževanja delno oziroma sploh ne plačujejo sami. Zato se moramo usmeriti v iskanje drugih finančnih virov. Predlagali smo poiskati pokrovitelje, ali izdelavo poučnih brošur. Prav tako pa smo ugotovili, da so fizioterapevti zelo zadovoljni z izobraževanji, saj jim znanje izobraževanj pomaga pri njihovem delovnem procesu.

Zaključimo lahko, da noben model vodenja ni idealen, pomembna je predvsem veščost vodij, da v dani situaciji uporabijo najprimernejši način vodenja. Izrednega pomena je zavedanje vodstva in vodij na njihovo vlogo, da se zavedajo odločujočega pomena znanja za konkurenčno prednost zavoda in da znajo zadržati ključne kadre. Zaposlenim, ki imajo cilj in željo po nadaljnjem izobraževanju, morajo nuditi podporo, izraziti strinjanje z odločitvijo, jih motivirati in spodbujati $\mathrm{k}$ realizaciji teh ciljev. To pa lahko dosežejo $\mathrm{z}$ ustrezno izdelano vizijo organizacije. V zdravstvu je vedno v središču pozornosti pacient, ki mu skušamo nuditi najbolj kakovostno storitev.

Raziskavo bi bilo zanimivo razširiti na večjem vzorcu, torej v vseh zdravstvenih domih v Sloveniji, saj je bila naša raziskava izvedena v zelo ozkem vzorcu. Tako bi lahko dobili tudi celostno sliko, kakšno pozornost dajejo vodje izobraževanju fizioterapevtov na primarni ravni $\mathrm{v}$ javnih zdravstvenih zavodih Slovenije.

Upam, da bo moja raziskovalna naloga koristno prispevala in da bo v pomoč predvsem tistim, katerim je interes povečati kakovost zdravstvenih storitev $\mathrm{v}$ javnih zavodih. 


\section{Reference}

1. Abrams, R. in Barrow, P. (2005). The Successful Business Plan; Secret and strategies. Chichester: Capstone Publishing.

2. Barle, A. in Bezenšek, J. (2006). Poglavja iz sociologije vzgoje in izobraževanja: Pregled sodobnih socioloških študij, perspektiv in konceptov. Koper: Fakulteta za management.

3. Buchhbinder, S. B. in Shanks, N. M. (2012). Introduction to Health Care Management (2. izdaja). Jones \& Bartlett Learning.

4. Černetič, M. (2007). Management in sociologija organizacij. Kranj: Moderna organizacija.

5. Česen, M. (2003). Management javne zdravstvene službe. Ljubljana: CTU, Center za tehnološko usposabljanje.

6. Dimovski, V., Penger, S., Peterlin, J., Grah, B., Turk, D., Šalamon, K. et. al. (2014). Temelji managementa in organizacije. Ljubljana: Ekonomska fakulteta Univerze v Ljubljani.

7. Huber, D. L. (2014). Leadership and Nursing Care Management (5. izdaja). Saint Louis: Elsevier Saunders.

8. Iqbal, N., Anwar, S. in Haider, N. (2015). Effect of leadershep style on employee performance. Arabian Journal of Business and Management Review, 5(5), 1-6.

9. Jelenc, S. (1996). ABC izobraževanje odraslih. Ljubljana: Andragoški center Republike Slovenije.

10. Kovač, J., Mayer, J. in Jesenko, M. (2004). Stili in značilnosti uspešnega vodenja. Kranj: Moderna organizacija.

11. Marquis, B. L. in Huston, C. J. (2015). Leadership Roles and Management Functions in Nursing: Theory and Application (8. izdaja). Philadelphia: Wolters Kluwer Health, Lippincott Williams \& Wilkins.

12. Medved Jereb, P. (2006). Izobraževanje fizioterapevtov ob delu v slovenskih bolnišnicah: diplomsko delo. Kranj: Univerza v Mariboru, Fakulteta za organizacijske vede.

13. Možina, S. (2002). Vodja in vodenje. V S. Možina, R. Rozman, M. Glas, M. Tavčar, D. Pučko, J. Kralj in drugi, Management: nova znanja za uspeh (str. 498-539). Radovljice: Didakta.

14. Možina, T. (2003). Kakovost v izobraževanju: od tradicionalnih do sodobnih modelov ugotavljanja in razvijanja kakovosti v izobraževanju odraslih. Ljubljana: Andragoški center Republike Slovenije.

15. Pučko, D. (2002). Uresničevanje strategij. V S. Možina, R. Rozman, M. Glas, M. Tavčar, D. Pučko, J. Kralj in drugi, Management: nova znanja za uspeh (str. 314-43). Radovljica: Didakta.

16. Pahor, M. (2014). Zavezniki za zdravje: medpoklicno sodelovanje v zdravstvenih timih. Ljubljana: Zdravstvena fakulteta; Univerza v Ljubljani.

17. Pavlin, B. (30. 1. 2015). Vlaganje v izobraževanje zaposlenih je najboljša naložba. Delo.si. Pridobljeno dne 7. 1. 2020 na https://www.delo.si/gospodarstvo/infrastruktura/vlaganje-vizobrazevanje-zaposlenih-je-najboljsa-nalozba.html

18. Rozman, R. in Kovač, J. (2012). Management. Ljubljana: GV Založba.

19. Rozman, R., Kovač, J., Filej, B. in Robida, A. (2019). Management v zdravstvenih organizacijah. Ljubljana: Lexpera, GV Založba.

20. Uhan Petek, M. (2008). Management vključevanja zavoda osnovnega zdravstvenega varstva v lokalnem okolju. V Sodobni vidiki vodenja v zdravstvu (str. 69-76). Ljubljana: Društvo ekonomistov v zdravstvu.

21. Urh, I. (2003). Učeča se organizacija. Sodobna pedagogika, 1, 122-139.

22. Vukovič, G. (2006). Metode usposabljanja kadrov. Kranj: Moderna organizacija.

23. Yukl, G. (2010). Leadership in organizations. Upper Saddle River, NJ: Prentice Hall. 
24. Združenje fizioterapevtov Slovenije, strokovno združenje (8. 1. 2020). Izpopolnjevanja. Pridobljeno 8. 1. 2020 na https://www.physio.si/

25. Zupančič, P. (2015). Kako izbrati ustrezen stil vodenja? Pridobljeno dne 5. 1. 2020 na https://e.ravnatelj.si/organizacija-in-vodenje-zavoda/vodenje-in-komunikacija/91-kako-izbratiustrezen-stil-vodenja

Arbulena Kokollari je leta 2018 pridobila strokovni naziv diplomirana fizioterapevtka. Nato je opravila pripravništvo v Univerzitetnem kliničnem centru v Mariboru. Trenutno na Fakulteti za zdravstvene vede v Mariboru opravlja magisterij managementa $\mathrm{v}$ zdravstvu in socialnem varstvu. Ob tem izvaja tudi zasebno fizioterapijo ter je spletna blogerka s področja fizioterapije in splošnega zdravja.

\section{Abstract: \\ The Influence of Leadership on the Education of Physiotherapists in the Health Center}

Research Question (RQ): We are interested in whether physiotherapists in the health center are educated, who most often encourage them to educate, what is their main obstacle to education and whether their acquired knowledge in education helps them in the work process.

Purpose: The purpose of the research is to determine whether the method of management influences the attitude of physiotherapists' employees towards education and knowledge.

Method: An experimental quantitative survey was conducted using primary and secondary data sources. Primary sources were obtained by means of a survey questionnaire, and a descriptive research method was used to obtain secondary sources, in the way of systematic review of Slovenian and foreign literature.

Results: We found that physiotherapists are mostly self-motivated to educate themselves. Of all the leaders in the health center, they are most encouraged by the main physical therapist. One of the main obstacles to education was financial resources. Physiotherapists, however, are very happy with the training, as their knowledge of training helps them a lot in the work process.

Organization: The results obtained are helpful to all health care managers and other employees in order to describe the current state of management, education and employee satisfaction. By interpreting these, we can see which areas can be further improved for better quality service.

Society: Education is of great importance in providing a better quality service and thus improving the outcome of the patient treatment process and thus increasing the efficiency and effectiveness of the institution.

Originality: The institute can only develop professionally with the continuous professional and personal development of its employees, which only allows for continuous education and further training and mutual cooperation of employees. The study obtained the first data on the education of physiotherapists at the primary level of health care and the impact of the management method.

Limitations/Future Research: Further research could extend the research to a larger sample. In this way, we could also get an overall picture of what kind of attention is being given by education managers to employed physiotherapists at the primary level of health care in Slovenia.

Keywords: health center, physiotherapy, guidance, education at work, encouragement to education, barriers to education.

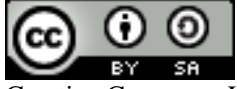

Creative Commons License

This work is licensed under a Creative Commons Attribution-ShareAlike 4.0 International License 